\title{
Household Fuel Transition and Determinants of Firewood Demand in Nepal
}

\author{
Bishnu Prasad Sharma, PhD \\ Associate Professor of Economics, Patan Multiple Campus, Tribhuvan University, \\ Nepal. \\ Email: bishnu@pmcecodtu.edu.np
}

\begin{abstract}
There is an emerging challenge of providing cleaner fuel to household to avoid various health risks arising from the use of traditional non-cleaner fuel and to cope with the challenges created by climate change. The energy transition theories explain how societies switch from traditional to more advanced fuels that are cleaner and efficient. The paper examines the state of fuel transition and determinants of firewood dependence in Nepal. This paper uses data collected in 2013 from three different ecological zones through household surveys. The findings revealed that biomass fuel particularly firewood is the dominant form of fuel used for household cooking with 84 percent dependence followed by LPG 9 percent, biogas 6 percent and electricity around 1 percent. The findings revealed that energy security through energy stacking is a dominant phenomenon. Presence of alternative fuel that are cleaner and convenient and ecological factors are major determinants of household firewood demand followed by literacy status, landholding size, household size, presence of large ruminant. Firewood consumption had negative relation with its price but the relation was not economically significant. In contrast to the study hypotheses, household income and remittance were not determining factors. In view of wider coverage of electricity, there is prospect for shifting to renewable fuel sources through appropriate pricing and technological improvement policies.
\end{abstract}

Key words: household energy, firewood, LPG, biogas, determinants.

\section{INTRODUCTION}

There is an emerging challenge of providing cleaner fuel to household to avoid various health risks arising from the use of traditional non-cleaner fuel and to cope with the challenges created by climate change (WHO, 2018).Household fuel choices are determined by a wide range of socio-economic factors (Lusambo, 2016; Giri \& Goswami, 2018; Makonese et al., 2018; Rathore \& Chauhan, 2018). There is a growing interest on cleaner and convenient fuels against traditional fuels such as biomass that is primarily dominated by firewood. The governments of Nepal had targeted for achieving 80 percent electrification through renewable energy source and reduce dependence on fossil fuels by 50 percent by 2050 (ADB, 2017). There is debate on whether rural electrification alone will lead to adoption of cleaner energy for major 
household energy use (WHO, 2018). The objective of this paper is to analyze the status of energy transition in rural communities in Nepal. It also analyzes the determinants of the adoption of firewood consumption by household for different ecological zones in Nepal.

Nepal's present primary energy supply mix indicates that around 81 percent of the fuel energy need is fulfilled by biomass energy while oil product constitutes 12 percent. The rest is coal 4 percent, and hydro-electricity 3 percent (ADB, 2017). The households are still the largest consumer of total energy consumption. For instance, residential consumption comprises of 84 percent followed by 7 percent in transport, 6 percent by industry, and 2 percent by commercial and public sector while one percent is used in agriculture. Due to high dependence of biomass consumption, Nepal's energy intensity was 0.41 tons of oil equivalents and about four times higher than the world average and it is the highest, largely because of inefficiencies in energy consumption (ADB, 2017).

The energy transition theories examines how societies switch from primitive to more advanced fuels that are cleaner and efficient (Berkhout et al., 2012). There are two theories of energy transition: the energy ladder hypothesis and energy stack model. The fuels energy ladder hypothesis examines the household fuel choice behavior of a utility maximizing neo-classical consumer. According to this hypothesis, as socioeconomic status improves, households switch from inferior (such as firewood) to superior fuels (bio-gas, electricity) based on physical characteristics including cleanliness, cooking speed, ease of use and cost efficiency. There are, however, debates on whether household incomes are the sole determinants of movement along the energy ladder (Gupta \& Kohlin, 2006; Campbell et al., 2003).

In contrast to the energy ladder model, the energy stacking model assumes household energy transition takes places through multiple fuel usage instead of a discrete steplike manner.

\section{LITERATURE REVIEW}

A large body of literature exists on the household energy consumption and its consequences on the environment in the form of forest degradation, indoor air pollution, outdoor air pollution etc. (Heltberg, 2005). There also exists various literature on the energy demand and the energy supply aspects. Similarly a range of studies are related to macroeconomic situations and energy consumption with its linkage to the environmental Kuznets curve (EKC). A wide range of studies have tried to establish relationship between household fuel choice and socio-economic determinants (Malla \& Timilsina, 2014; Rathore \& Chauhan, 2018). Rathore and Chauhan (2018) for instance examined how budget share on firewood is determined by per capita expenditure, household size and price of alternative fuel. 
Traditional and unclean fuel use and its consequences on human health, human resource development and ultimately on poverty spiral have been quite common (Heltberg, 2005). Public policy interventions have taken place in the form of subsidies on the purchase of cleaner fuels, innovations on cleaner technologies and outright public provision of cleaner fuel equipment such as clean cook-stoves. However, most of the interventions aimed at promoting clean cooking stoves focus only on technical aspects, such as their efficiency and the achievable emissions reductions, whereas the social, cultural and economic suitability of new stoves determine their continued use (Malla \& Timilsina, 2014). New lights have been shed on the existing factors for instance not only the family size but the number of families is a more reliable predictor of the total biomass consumption through the economies of scale (Knight \& Rosa, 2012). This is particularly true in the context of newly modernizing societies in the developing countries. In such societies, the traditional joint family systems break down with more preferences for nuclear families. This study aims to fulfill this knowledge gap in a highly transitory economy like Nepal which has remained economically stagnant internally but has been subject to rapid social changes induced by external factors such as remittance income and technological penetration brought about by expansion of transportation and communication networks. The paper also identifies prospects of energy transition given the development of the various energy potentials in Nepal.

\section{METHODS}

\section{Sources of Data}

This study uses data collected by the author for a different purpose from forest communities in three districts Dolkha, Gorkha and Chitwan representing the mountain, hills and the terai respectively. The data collected represented 21 community forest groups. Fifteen household were sampled randomly in proportion to three major ethnic groups: the Bramhin/Chhetri, the indigenous communities and the Dalits from each of the 21 communities. Altogether 315 households were selected among which 309 households were available for survey. Data were collected in 2013 between the months of AugustNovember with one year period before the date of survey as reference period.

Questionnaire interviews were administered to collect a wide range of information. This information comprised of household rooster, landholding, distance to forests, access to infrastructure, forest product extractions, fuel types and their intensity of use, household consumption expenditure among others. The household energy in cooking purpose was obtained for different types of sources that comprised of firewood, LPG, biogas, kerosene and electricity and their respective shares.

Data were analyzed to examine the fuel use transition for household cooking. Economic, social and access factors were analyzed to examine the determinant of firewood consumption. The relationship between firewood and other fuel has also been analyzed. 


\section{Empirical Model}

The determinants of firewood demand was analyzed using a log level regression equation using the ordinary least square method. The empirical model is given as equation (1). The dependent variable is the natural log of the total loads of firewood collected by the household annually from all available sources. Two household with no firewood use were removed from the analysis leaving a total of 307 households in the analysis. The explanation of the explanatory variables is provided in Table 1.

LnFIREWOOD $=b_{0}+b_{1}$ LARGE_RUMINANT $+b_{2}$ PER_CAPITA_CONSUMP + $\mathrm{b}_{3}$ REMIT_HH $+\mathrm{b}_{4}$ HOUSEHOLD_SIZE $+\mathrm{b}_{5}$ LITERATE_HH_HEAD + $\mathrm{b}_{6}$ DIST_MARKET $+b_{7}$ DIST_CF + $b_{8}$ HAVE_BIOGAS + $b_{9}$ HAVE_LPG $+b_{10}$ PRICE $++b_{11}$ MOUNTAIN DUMMY $+b_{12}$ TOT_LANDHOLDING $+\mu_{\mathrm{I}}$

Where $b 0$ is the constant terms and $b 1, \ldots, b$ bare the coefficients and $\mu$ is are the stochastic error terms for the equations. This study hypothesize that the relation between the major variables discussed in the literature with appropriate contextualization in the local context will be as follows for the three major energy sources for household $(\mathrm{HH})$ cooking. Some relations are not clear and we leave it for their empirical testing. Households are clustered for the 21 communities to ensure robustness in the regression results.

Table 1: Explanatory Variables and Their Expected Signs in the Empirical Model

\begin{tabular}{lll}
\hline Explanatory variables & Explanation of variable & Hypothesis \\
\hline LARGE_RUMINANT & Number of large ruminant units & +ve \\
PER_CAPITA_CONSUMPT & $\begin{array}{l}\text { Per capita consumption of household } \\
\text { Remittance household dummy, remittance } \\
\text { REMIT_HH }\end{array}$ & -ve \\
recipient $=1$, else 0 & -ve \\
HOUSEHOLD_SIZE & Size of the household & +ve \\
DIST_MARKET & Literacy dummy literate =1, else 0 & -ve \\
DIST_CF & Distance to nearest market for LPG cylinder & +ve \\
HAVE_BIOGAS & Time taken to fetch firewood from CF & -ve \\
HAVE_LPG & Biogas dummy, HH has biogas installed=1, else=0 & -ve \\
PRICE & HH uses LPG stove & -ve \\
MOUNTAIN_DUMMY & Price of firewood & -ve \\
TOT_LANDHOLDING & district=1, else $=0$ & + Total landholding in hectares \\
\hline
\end{tabular}


This study hypothesizes that large ruminant units has a positive relationship with firewood. Higher per capita consumption is hypothesized to shift households to cleaner fuel thus reducing the demand for firewood (Rathore \& Chauhan, 2018; Malla \& Timilsina, 2014; Lusambo, 2016). Remittance has a psychological effect of inducing households to assume that they are better off and motivate them to shift to cleaner fuel. Household size is assumed to increase firewood demand as large household need larger vessel for cooking that is possible only with firewood stoves (Rathore \& Chauhan, 2018). Literacy of household head is hypothesized to reduce firewood demand due to higher awareness against indoor air pollution from firewood stoves (Assa et al., 2015; Lusambo, 2016).

The distance to the market is assumed to act positively to firewood demand. Higher the distance, lower the chances to shift to cleaner fuel due to transportation difficulty. Distance to community forests $(\mathrm{CF})$ is also assumed to have a positive relation with firewood demand. Availability of cleaner and convenient fuels such as biogas plant and LPG stoves are hypothesized to have a negative effect with firewood due to substitutability. Price of firewood is assumed to be guided by economic theory of demand and is considered to have a negative relation with quantity of firewood consumed.

Mountain dummy is considered as an ecological dummy for households located in mountain district where weather is cold throughout the year and causes higher firewood demand for household heating and cooking. The analysis examines the mountain region versus the hills or the terai region. Total landholding is considered a resource variable that induces firewood consumption that is produced through natural regeneration at almost no cost. Household with large landholding have naturally higher firewood production due to the agro-forestry system practiced in Nepal where trees grow in abundance on waste lands and terraces.

\section{FINDINGS}

\section{General Household Characteristics}

The socio-economic analysis of data indicated that indigenous communities constituted the largest share of the population (55.7) followed by 32.7 percent and the Dalit population 11.7 percent. The average household size was 4.9 persons and the mean age of household head was 52 years. The percentage of literate households was 50 . These comprised of both kinds of education, formal schooling as well as functional literacy in with general ability to read, write and undertake simple calculations. Ninety percent of the total households had permanent toilets. Twenty percent of the total households had at least one member in foreign employment. The average distance to a reliable market centre was around 100 minutes away from home. The average distance to the $\mathrm{CF}$ was about half an hour from residence. 
Regarding fuel type, annual firewood consumption was 63 backloads. Around ten percent households had bio-gas installed for household cooking. The households had a mean per capita consumption of Rs 62.4 thousand with a standard deviation of Rs. 79 thousand. The total landholding was 0.7 hectares per household.

\section{Fuel Type and Dependence}

Analysis of the fuel types and their respective dependence were analyzed to examine the trend of energy transition and energy stacking. The findings of dependence on various types of energy sources revealed that firewood was the most depended energy source for household cooking with around 84 percent dependence. This was followed by LPG, biogas and electricity. Kerosene was almost non-existent.

Table 2: Fuel Type and Dependence by Ecological Regions (Percent of Households)

\begin{tabular}{lrrrr}
\hline Fuel Type & \multicolumn{1}{c}{ Mountain } & Hills & Terai & \multicolumn{2}{c}{ Total } \\
\hline Firewood & 96.80 & 71.09 & 82.52 & 83.73 \\
LPG & 1.78 & 18.32 & 8.47 & 9.37 \\
Biogas & 0.93 & 9.50 & 8.37 & 6.17 \\
Electricity & 0.47 & 1.09 & 0.64 & 0.73 \\
Kerosene & 0.02 & 0.00 & 0.00 & 0.01 \\
\hline Total & 100.00 & 100.00 & 100.00 & 100.00 \\
\hline
\end{tabular}

Source: Field survey, 2013

The full dependence on single fuel was analyzed to examine the energy transition. The findings revealed that though there was overall 84 percent share of firewood in household cooking overall, household depending on firewood alone was only 35 percent and they supplemented firewood by other sources. People depending only on LPG were less than one percent while those depending wholly on other sources such as biogas, kerosene or electricity were nil. This indicates that energy transition is still not a feature of Nepalese household sector.

Table 3: Fuel Type and Percentage of Households Adopting (percent of households)

\begin{tabular}{lllll}
\hline Fuel for HH cooking & Mean & Std. dev. & Min & Max \\
\hline Only Firewood & 34.63 & 47.66 & 0.00 & 100.0 \\
Only LPG & 0.65 & 8.03 & 0.00 & 100.0 \\
Only Biogas & 0.00 & 0.00 & 0.00 & 0.00 \\
Only kerosene & 0.00 & 0.00 & 0.00 & 0.00 \\
Only electricity & 0.00 & 0.00 & 0.00 & 0.00 \\
\hline
\end{tabular}

Source: Field survey, 2013 
On the flip side this study examined how households complemented firewood with other sources of household energy. Firstly, this study examined what single additional source sources they used to supplement firewood. The percentage of households using a combination of firewood and LPG were 17 percent while household using firewood with bio-gas were 6 percent. Surprisingly, electricity was the largest supplementing energy source to firewood and this was practiced by almost one third of the total households. Despite such a high percent using electricity to complement firewood energy, electricity as a share of total energy consumption constitutes less than half percent. This indicates that electricity is used only for non-energy consuming cooking activities such as boiling tea, boiling water for drinking among others.

Table 4: Fuel Combination with Firewood (Percentage of Households)

\begin{tabular}{lrrrc}
\hline HH using Combination with firewood & \multicolumn{1}{c}{ Mean } & Std. dev. & Min & Max \\
\hline LPG & 16.50 & 37.18 & 0.00 & 100.00 \\
Biogas & 6.15 & 24.06 & 0.00 & 100.00 \\
Electricity & 33.33 & 47.22 & 0.00 & 100.00 \\
Kerosene & 0.00 & 0.00 & 0.00 & 100.00 \\
\hline
\end{tabular}

Source: Field survey, 2013

Secondly, we examined how households supplemented household energy with a third energy source beside firewood and its main complement. We found that households using a combination of firewood, LPG and biogas were 1.6 percent while those using LPG and electricity with firewood were 4.5 percent. Households using biogas with electricity was around 3 percent.

Table 5: Joint Fuel Combination with Firewood (Percent of Households)

\begin{tabular}{lllll}
\hline HH using combination with firewood & Mean & Std. dev. & Min & Max \\
\hline LPG and biogas & 1.62 & 12.64 & 0.00 & 1.00 \\
LPG and electricity & 4.53 & 20.83 & 0.00 & 1.00 \\
Biogas and electricity & 2.91 & 16.84 & 0.00 & 1.00 \\
\hline
\end{tabular}

Source: Field survey, 2013

These findings indicate that household cooking fuel stacking is the major practice. Firewood remains the major cooking fuel source supplemented by other fuel. Other fuel were used as supplement to address seasonal variation in firewood collection, is case of urgency such meeting children's school time, when it is too hot in the daytime to cook in firewood etc. We might find some other stacking such as LPG and electricity in urban areas but that would be negligible. 


\section{Determinants of Firewood Demand by Household}

This study assumes that the household fuel energy depends upon various socioeconomic and resource access variables. The socioeconomic variables are the age of the household head, literacy status, household size, size of landholding, livestock units, remittance income, time taken to reach market center for LPG, time taken to collect firewood from community forest, use of LPG and biogas, household landholding.

Price is the economic factor determining the consumption of firewood. Price of firewood was not explicit in many communities because market for firewood did not exist. In that case households were asked what minimum amount they would be willing to receive if they have to bring a back load of firewood from some open access for some neighbor on a regular basis. Some households were also asked what maximum amount they would be willing to pay if there is a shortage of LPG they are currently using and they have to resort to firewood. Some communities had references of teashops which purchased firewood on a regular basis.

Table 6: Summary Statistics of the Explanatory Variables

\begin{tabular}{lllll}
\hline Variable & Mean & Std. Dev. & Min & Max \\
\hline LARGE_RUMINANT & 2.39 & 2.20 & 0.00 & 17.00 \\
PER_CAPITA_CONSUMPT & 61732.36 & 78725.10 & 10264.67 & 709649.10 \\
REMIT_HH & 0.25 & 0.43 & 0.00 & 1.00 \\
HOUSEHOLD_SIZE & 4.87 & 2.11 & 1.00 & 15.00 \\
LITERA_HH_HEAD & 0.47 & 0.50 & 0.00 & 1.00 \\
DIST_MARKET & 98.00 & 71.41 & 1.00 & 320.00 \\
DIST_CF & 33.13 & 43.61 & 2.00 & 420.00 \\
HAVE_BIOGAS & 0.10 & 0.30 & 0.00 & 1.00 \\
HAVE_LPG & 0.24 & 0.43 & 0.00 & 1.00 \\
PRICE & 403.33 & 328.87 & 106.43 & 1963.33 \\
MOUNTAIN_DUMMY & 0.35 & 0.48 & 0.00 & 1.00 \\
TOT_LANDHOLDING & 0.68 & 0.65 & 0.00 & 5.09 \\
\hline
\end{tabular}

Source: Field survey, 2013

The results from log-level regression equation using ordinary least square indicated that fuel wood share in household cooking with various other socio-economic and access variables indicated that the size of large ruminant units, the household size, literacy status of household, presence of biogas or LPG stoves, price of firewood, ecological belt and total landholding are several factors determining the demand for firewood. 
The findings indicated a positive relationship between livestock units and firewood demand. An addition of one large ruminant unit increases firewood demand by around 4 percent. The household size also had a positive relationship with firewood demand. Back loads of firewood consumption increased by 4 percent for each additional family member A household head being literate reduced the probability of firewood consumption by 8 percent. This was because literate household heads were more health conscious of the negative impact of smoke pollution. Having a biogas in general reduced firewood use by around five 48 percent for the household while the existence of LPG stove to complement household energy reduced the use of firewood by 26 percent. The impact of price on firewood consumption was negative indicating an inverse relationship between the opportunity cost of firewood collection and firewood consumption. However, the magnitude of the effect was not economically significant. This indicates that firewood is still a necessary good in Nepalese rural community.

The ecological belt dummy indicates that a household in mountain belt increases firewood consumption by 11 percent compared to their mid hill and Terai counterparts. The total landholding per hectare also increases the use of firewood by 7 percent due to the firewood by products created by the agroforestry system.

Table 7: Determinants of Loads of Fuel-Wood in Household Consumption (Loads of Firewood Consumed In Natural Log Form as Dependent Variable)

\begin{tabular}{lllll}
\hline Explanatory Variables & Coefficient & Rob Std. Err. & t-statistics & P>t \\
\hline LARGE_RUMINANT & $0.0358^{* * *}$ & 0.0129 & 2.7700 & 0.0120 \\
PER_CAPITA_CONSUMPT & 0.0000 & 0.0000 & 0.0000 & 0.9980 \\
REMIT_HH & -0.0739 & 0.0522 & -1.4200 & 0.1720 \\
HOUSEHOLD_SIZE & $0.0375^{* * *}$ & 0.0067 & 5.6000 & 0.0000 \\
LITERA_HH_HEAD & $-0.0779^{* *}$ & 0.0344 & -2.2700 & 0.0350 \\
DIST_MARKET & 0.0000 & 0.0003 & -0.1200 & 0.9020 \\
DIST_CF & 0.0006 & 0.0004 & 1.4300 & 0.1670 \\
HAVE_BIOGAS & $-0.4828^{* * *}$ & 0.1202 & -4.0200 & 0.0010 \\
HAVE_LPG & $-0.2629^{* * *}$ & 0.0522 & -5.0300 & 0.0000 \\
PRICE & $-0.0002^{* * *}$ & 0.0000 & -3.6800 & 0.0010 \\
MOUNTAIN_DUMMY & $0.1095^{* *}$ & 0.0522 & 2.1000 & 0.0490 \\
TOT_LANDHOLDING & $0.0660^{*}$ & 0.0318 & 2.0800 & 0.0510 \\
CONSTANT & $3.9309^{* * *}$ & 0.0741 & 53.0200 & 0.0000 \\
\hline
\end{tabular}

Source: Author's estimation.

Note: ${ }^{*}, * *$, and ${ }^{* * *}$ indicate significance level at 10 percent, 5 percent and 1 percent respectively. 
The F statistics was statistically significant at 1 percent level while the adjusted $R$ squared was 0.42 . This $\mathrm{R}$-squared value can be considered large enough in case of cross sectional data. The estimates were robust due to clustering of households by $\mathrm{CF}$ groups.

\section{DISCUSSION}

The finding of the analysis sheds important lights in the energy consumption behavior in Nepal. The total household energy comprises of energy used for household cooking, energy used in preparing animal feed and energy used for household heating during cold. The findings indicated that households' energy practice is basically energy stacking with large dependence on firewood due to the nature of the agro-forestry based farm system. A different result might be obtained for rural and urban communities.

The results also indicate an important policy perspective. Electricity occupies second most preferred alternative to firewood. It could be mainly due to the prices, supply irregularity and other physical requirement that have deterred households from adopting electricity for household cooking. If electricity prices can be made affordable, supply regular and provided with efficient stoves, electricity could substitute for LPG and other forms of household cooking fuel.

Regarding the demand for firewood, the size of large ruminant units, presence of alternative sources that are cleaner and efficient such as biogas and LPG had major effect in household firewood consumption. Biogas installation reduced firewood consumption of household by almost half. The supplement of LPG also reduced firewood consumption by about a quarter of firewood use. Location of household by ecological belt was found an important determinant of firewood use. Household in the mountain region had 11 percent more firewood demand compared to their hill and Terai counterparts. Literacy status of household head was another important factor reducing household firewood demand indicating that literate household would reduce their firewood demand by around 8 percent compared to non-literate household head. The awareness of air pollution induced health impacts could be the possible reason for aversion of firewood use. This finding concurs with a wide range of earlier studies such as (Giri \& Goswami, 2018; van der Kroon et al., 2013). The size of land holding was also found to be positively related with firewood share in cooking due to the practice of agro forestry. Households with large lands have trees in their own lands that make use of firewood economical as well as compelling as thinning and pruning to remove tree from covering agriculture land produces enough firewood as a by product.

Another determinant was household size. Household with large household size need to cook in large vessels and is convenient with firewood cooking. Livestock keeping 
had a positive effect on household firewood demand. This is because in most rural communities, livestock keeping requires collection of firewood for cooking gruel for livestock and collecting firewood from various sources becomes compelling. Upscaling the collecting activity makes it economically rational for households to use firewood for household cooking too.

In contrast to the expectation, there was no impact of per capita consumption, a proxy of household's standard of living with firewood consumption. This finding contradicted with some earlier studies by Rathore and Chauhan (2018).Remittance was hypothesized to have a negative impact on firewood consumption as household were expected to shift to cleaner and convenient fuel such as LPG and biogas with remittance income. However, there was no impact of remittance on household firewood consumption too. The findings matched with Heltberg (2005), that distance to community source did not affect use of firewood switching.

The energy ladder theory explains that as families gain socioeconomic status they abandon technologies that are inefficient, less costly and more polluting and move from traditional to middle category fuels such as charcoal, coals or kerosene. In the last phase households switch fuels such as LPG and electricity (van der Kroon et al, 2013). Masera et al. (2000) had long ago produced evidence that higher ranked fuels are usually more efficient and costly, but require less input of labour and produce less pollution per unit of fuel. In this context, the analysis of the fuel use by households indicates that Nepal has stepped into the energy transition ladder but is still at its very bottom. Lower level fuels in the energy ladder indicate that fuel collection requires more time and is more polluting. It produces more adverse impact on the environment due to deforestation and land degradation. Unclean fuel leads to poor health among child, women and elderly that inversely related to labour productivity and economic contribution to household income (Rao \& Reddy, 2007).

\section{CONCLUSIONS}

There is a growing concern on improving livelihood of the average and poor families and protecting communities from the adverse effects of climate change. The energy sector is one of the sectors that have multidimensional effects on improving the livelihood and climate change effect mitigation. Shifting from non-renewable energy to renewable and cleaner energy leads to household welfare improvement, improved health and environmental conservation simultaneously. LPG is the second relied source following firewood in total share of household cooking energy. However, the evidence produced by this analysis indicated that electricity is a second important resource at household's access (33 percent households) after firewood. Only 17 percent households use LPG besides firewood. Several studies have emphasized on energy 
stacking rather than energy transition as a more practicable solution to address energy problem (van der Kroon et al, 2011). The evidence produced by this study supports this approach

Government provision to promote electricity for household cooking is highly relevant in the context of Nepal when the country is going to have a surplus of electricity in the near future. Nepal Electricity Authority (NEA, 2018) reports that 70 percent of the total population has access to grid electricity supply. The authority which is currently managing 1500 megawatt (MW) electricity has expected to add $1200 \mathrm{MW}$ within the next 2-3 years and has already signed power purchase agreements with independent power producers (IPPs) for $4500 \mathrm{MW}$. In this context there is a need for developing appropriate pricing and technological improvement policy to promote electricity consumption at household level.

\section{References}

ADB. (2017). Nepal energy sector assessment, strategy, and road map. Asian Development Bank. DOI http://dx.doi.org/10.22617/TCS178936-2

Assa, M. M., Maonga, B. B., \& Gebremariam, G. G. (2015). Non-price determinants of household's choice of cooking energy in Malawi. International Journal of Development and Sustainability, 4(1), 18-28.

Berkhout, F., Marcotullio, P., \& Hanaoka, T. (2012). Understanding energy transitions. Sustainability Science, 7(2), 109-111.

Campbell, B. M., Vermeulen, S. J., Mangono, J. J., \& Mabugu, R. (2003). The energy transition in action: Urban domestic fuel choices in a changing Zimbabwe. Energy Policy, 31, 553-562.

Giri, M., \&Goswami, B. (2018). Determinants of household's choice of fuel for cooking in developing countries: Evidence from Nepal. Journal of Development Policy and Practice, 3(2), 137-154.

Gupta, G., \&Köhlin, G. (2006). Preferences for domestic fuel: Analysis with socioeconomic factors and rankings in Kolkata, India. Ecological Economics, 57(1), 107-121.

Heltberg,R.(2005). Factorsdetermininghousehold fuelchoiceinGuatemala.Environment and Development Economics, 10, 337 361. DOI: https://doi.org/10.1017/ S1355770X04001858

Knight, K. W., \& Rosa, E. A. (2012). Household dynamics and fuel wood consumption in developing countries: A cross-national analysis. Population and Environment, 33, 365-378. 
Lusambo, L. P. (2016). Household energy consumption patterns in Tanzania. J Ecosyst Ecography, S51.DOI: 10.4172/2157-7625.S5-007

Makonese, T., Ifegbesan, A. P., \& Rampedi, I. T. (2018). Household cooking fuel use patterns and determinants across southern Africa: Evidence from the demographic and health survey data. Energy \& Environment, 29(1), 29-48.

Malla, S., \& Timilsina, G. R. (2014). Household cooking fuel choice and adoption of improved cook stoves in developing countries: A review. The World Bank.

Masera, O. R., Saatkamp, B. D., \& Kammen, D. M. (2000). From linear fuel switching to multiple cooking strategies: A critique and alternative to the energy ladder model. World development, 28, 2083-2103.

NEA. (2018). Annual report 1018. Kathmandu: Nepal Electricity Authority, Government of Nepal.

Rao, M. N., \& Reddy, B. S. (2007). Variations in energy use by Indian households: An analysis of micro level data. Energy, 32(2), 143-153.

Rathore, P., \& Chauhan, N. (2018). Sustainable development and fuel choice: A case study of India. OIDA International Journal of Sustainable Development, 11(5), 4150.

van der Kroon, B., Brouwer, R., \& Van Beukering, P. J. (2011). The energy ladder: Theoretical myth or empirical truth? Results from a meta-analysis. Renewable and Sustainable Energy Reviews, 20, 504-513.

WHO. (2016). World health statistics 2016: Monitoring health for the SDGs sustainable development goals. World Health Organization. 